\title{
15 The Demand for Work-Family Policies in Advanced Capitalist Democracies
}

This chapter explores the conditions under which voters demand work-family policies (WFPs) - that is, social policies that aid families, and especially mothers, in balancing formal employment with family life. ${ }^{1}$ While governments in a number of industrialized democracies have, since the 1970s, cut other welfare programmes, such as unemployment insurance (Allan \& Scruggs, 2004), they have considerably expanded WFPs such as parental leave and day care services (Ferragina, SeeleibKaiser, \& Tomlinson, 2012; Fleckenstein, Saunders, \& Seeleib-Kaiser, 2011). Welfare state institutions are thus fundamentally changing. If public policies at least to some extent are a function of voters' policy preferences, then studying the popular demand of WFPs is paramount for understanding this transformation of the welfare state. Most existing analyses of the expansion of WFPs often implicitly assume that the passing of these policies is partly or wholly driven by the demands and needs of employed women, either as voters, parliamentarians or members of women's movements (Bonoli \& Reber, 2010; Häusermann, 2006; Huber \& Stephens, 2000; Leira, 2002; Morgan, 2006, 2013). Yet few of the studies of WFPs offer a theory or any empirical evidence regarding which voters should prefer these policies. They are thus unable to explain the large variation in support for WFPs, across both individuals and countries.

The first contribution of this chapter is to address this shortcoming in the existing literature by focusing on bargaining within the household institution. Theoretically, I draw on and extend Iversen and Rosenbluth's (2006, 2010) household bargaining theory of gender differences in political preferences (see also King \& Mason, 2001; Lundberg, 2008). I argue that employed and, even more, highly educated women demand WFPs more than other individuals. This is because WFPs enhance their economic independence after childbirth and increase their potential to participate in the labour market. I also contend that there is a decisive difference between day care services and paid parental leave policies. Day care services, being available to all with means-tested payments, are more redistributive than leave policies, which are positively related to previous earnings. This means that whereas employed women in all parts of the income distribution will demand leave policies, low-income women will

1 I wish to particularly thank Fredrik Engelstad for comments on several previous drafts of this chapter. I also want to thank Bastian Betthäuser, Laura Bronner, Cathrine Holst, Magnus B. Rasmussen, David Rueda, Aksel Braanen Sterri and Gunnar Aakvaag as well as the participants at the Challenges to Democracy Conference for helpful comments on previous versions of this chapter. Parts of the chapter are based on my MPhil thesis. 
demand day care services more than upper-income women. Empirically, I examine this argument using survey data from the International Social Survey Programme in 1994 and 2002, which contains questions about WFPs and covers more than 40,000 respondents across 20 advanced capitalist democracies. I find clear support for the household bargaining model.

The second contribution of this chapter is to investigate labour market institutions that are associated with cross-country differences in the demand for WFPs. A number of studies emphasize and demonstrate how macro-level institutions, such as labour market structures, both influence and are influenced by voters' policy attitudes (Gingrich \& Ansell, 2012; see e.g. Rehm, 2011). Notwithstanding this research and the fact that WFPs are labour market policies, we know little about how labour market institutions affect the demand for WFPs. Thus, to explore the cross-country differences in demand, I look at how day care services and paid parental generosity, skill specificity and wage inequality are associated with cross-country variations in demand for day care and parental leave. These factors have been argued to affect individuals' demand for social policies. I find some evidence that greater WFP generosity, higher skill specificity and lower income inequality are associated with more demand for WFPs. In other words, not only women's access to education and employment but also macro institutions are associated with the demand for WFPs.

In sum, by looking at the demand for WFPs, this study contributes to our understanding of when and why parties may be expected to expand WFPs and why different WFPs may entail different political dynamics based on their redistributive consequences. This should also help us to better understand the causes of the changing nature of the welfare state, in which WFP plays an increasingly prominent role (Morel, Palier, \& Palme, 2012).

\subsection{A Brief Conceptualization of Work-Family Policies}

Family policies form part of a larger set of welfare policies that include a wide range of social services and transfers. We can divide public family policies into two broad types: 'WFPs' and 'male-breadwinner policies'. This chapter focuses on the former. Male-breadwinner policies refer to policies that give households incentives to adopt a gendered division of work, in which one member of a couple specializes in household work, usually the woman, and the other takes part in the formal labour market. One example is family allowances that are tied to the income of a male worker. WFPs, on the other hand, are policies that (i) allow spouses, especially employed women, to take leave to care for their newborn without experiencing a significant reduction in their income or chance of re-entering the labour market thereafter and/or (ii) that enable and often encourage both spouses to participate in the labour market while they have young children. 
We can distinguish between three main types of WFPs: day care services, maternity and parental leave and work-time arrangements (the possibility to undertake parttime work) (Morgan, 2006, p. 8). This chapter is concerned with day care services and maternity and parental leave benefits for two reasons. First, day care services and leave policies are, and have been for the last 40 years, among the most politically salient policies for addressing the gendered division between paid and household work and for making it possible for employed women and dual-earner families to balance their work and family responsibilities (Leira, 2002; Michel \& Mahon, 2002; Morgan, 2006). Consequently, if we wish to understand the development of WFPs and the changing nature of the welfare state, day care services and leave policies are the two most important policies to examine. Due to their political salience, these policies have also been at the heart of the previous research on WFPs.

Second, focusing on both day care services and leave policies gives us a chance to investigate the provision of both services and transfers (see also Jensen, 2011). As emphasized by a number of scholars, welfare services, such as day care services, are more redistributive across income groups than transfers, such as leave policies (Esping-Andersen, 1990; Hinnfors, 1999; Huber \& Stephens, 2000, p. 326; Iversen \& Cusack, 2000, p. 329). This means that the dynamics of both voter demand and political supply are likely to vary between the two WFPs investigated in this paper. Transfers, including leave policies, are usually paid according to previous earnings, meaning that they preserve income differentials. Where publicly provided or funded day care services are available, on the other hand, access is often given equally to all children. Payment for day care services is also usually means-tested, meaning that parents with low income pay less than those with high income. Moreover, in the absence of day care services, families and individuals with high income can buy day care services from the market without subsidizing low-income parents through the tax system. The implication is that day care services are redistributive, and more so than leave policies.

Since not all designs of day care services and leave policies can be seen as enhancing women's position in the labour market and making it possible for them to balance their paid work and family responsibilities, we need to define these policies more precisely. Policies aimed at caring for children under school age can be divided into preschool and day care programmes. Preschool programmes aim to educate children, and their part-time character does not match the needs of parents in full-time employment (Morgan, 2006, pp. 8-9). They are also often aimed only at children approaching school age rather than younger children. In contrast, day care programmes are also available for younger children and directly geared towards looking after the children while their parents are at work. The generosity of day care services refers not only to the availability of services for children below school age but also to whether it is provided on a full-time basis, how costly it is for the parents and the skills and qualifications of the personnel (Mahon, 2002, p. 5). 
Regarding leave policies, maternity leave refers to programmes designed for women immediately before and after birth. Parental leave follows maternity leave and can often be split between the parents, although the exact rules vary widely by country. Fathers may take a share of the parental leave, but in practice a large share of the parental leave is taken by women in most OECD countries (OECD, 2012a, pp. $4-5) .^{2}$ Regarding the generosity of leave policies, we can distinguish between two elements, namely the wage replacement rate and the length of the benefit. ${ }^{3} \mathrm{~A}$ number of studies suggest that paid leave enhances women's possibility to participate more fully in the labour market (Akgunduz \& Plantenga, 2012; Erosa, Fuster, \& Restuccia, 2010; Rasmussen, 2010; Rønsen \& Sundström, 1996), although leave periods longer than two years may have a negative effect on their later return to paid employment (Thevenon \& Solaz, 2013).

\subsection{Household Bargaining and the Demand for Work-Family Policies}

To explain the divergent preferences for WFPs among voters, I will draw on studies that use a household bargaining framework to account for spouses' division of household work and gender differences in policy and political preferences (Blau, Ferber, \& Winkler, 2010; Iversen \& Rosenbluth, 2006, 2010; King \& Mason, 2001; Lundberg, 2008; Lundberg \& Pollak, 2008; Xu, 2007). In household bargaining, the spouses, implicitly or explicitly, bargain over the division of household and paid work. I draw in particular on Iversen and Rosenbluth's $(2006,2010)$ insights into the role of household bargaining for individuals' preferences. Although they mention daycare, their focus is on the spouses' division household and paid work, on partisan preferences and on preferences for public employment. In contrast, my focus is on understanding the demand for both leave policies and day care services, which again lays the foundation for understanding parties' supply of WFPs. I agree with the authors on the role of employment among women but also highlight the role of higher education and the different role of income for leave policies and day care services (see below).

The use of a household bargaining framework based on material self-interest as a starting point requires some justification. In this framework, spouses bargain

\footnotetext{
2 For instance, even in Denmark only 26 percent of fathers took some parental leave in 2011. Some countries also have a separate paternity leave, but it is normally of very short duration (Moss, 2012). 3 In addition, paid parental leave is often capped at a certain level of income. In Norway, for instance, paid parental leave is capped at six times the 'basic amount', which in 2016 amounted to $6 \times 7,715=$ NOK 46,290, or about USD 5,500 per month. With an average monthly (pre-tax) salary of NOK 43,300, the cap is at approximately the average income.
} 
over family priorities and seek to achieve an outcome that is closer to their own preferences. Thus, it allows spouses to have diverging preferences and care about their own welfare. Other approaches have argued that households can be seen as having unitary preferences (see Becker, 1981) or that both spouses' preferences are predominantly formed by the broader culture and attitudes in a given society (PfauEffinger, 1998, 2004). Regarding the former, mounting evidence, both experimental and observational, suggests that a wide range of topics - such as the division of household work, household consumption patterns and policy preferences - are better explained by a bargaining framework than the unitary preference model, both in developing and developed countries (King \& Mason, 2001; for reviews see $\mathrm{Xu}$, 2007). Regarding the cultural approach, recent studies suggest that cultural attitudes towards gender equality are more likely to follow rather than precede the entrance of women into the labour market (Albanesi \& Olivetti, 2007; Goldin, 2006; Iversen \& Rosenbluth, 2010; Ross, 2008) and that women's employment situation forms their attitudes more than the existence of a selection effect into employment or domestic work based on previous attitudes (Berrington, Hu, Smith, \& Sturgis, 2008, p. 108; Cunningham, 2007). Thus, using a household bargaining framework seems more viable than the existing alternatives that could have been used as a starting point for understanding individuals' preferences for WFPs. It is a parsimonious approach that has proven to be empirically powerful for explaining spouses' behaviours and preferences in a wide range of settings. I therefore adopt it here. My contribution is to apply this approach to explain the preferences for both leave policies and day care services, to highlight the role of higher education for women and to emphasize the different redistributive effects of leave policies and day care services.

In the household bargaining model, I start out with a household consisting of a woman and a man who may have diverging preferences and therefore 'bargain' over family priorities, such as who undertakes paid work, housework, day care etc. (Blau et al., 2010, pp. 45-46). It is assumed that every agreement between these two persons must render each at least as well off as they would be without any agreement (i.e., divorce or breakup) (Lundberg \& Pollak, 2008). The main idea is that each person's bargaining power stems from their willingness to walk away from the deal - which again is determined by 'outside options', referring to 'the well-being that each would attain if they cannot reach agreement within the marriage' (Blau et al., 2010, pp. 45-46). Here, marketable skills, such as having higher education, can be used to attain well-being outside the marriage, whereas household-specific skills are not employable outside the marriage. The final bargaining solution is likely to reflect more closely the preferences of the person that has less to lose from no agreement - that is, the person with the most marketable skills (who thereby has the highest bargaining power) (Iversen \& Rosenbluth, 2010, p. 52; Lundberg, 2008). In other words, the spouse in possession of better outside options, such as higher education and stable paid employment, will be more able to have their way in the marriage or 
partnership. The household model thus takes seriously the power relations within the family, or household, institution.

Why is this important for understanding preferences for WFPs? The logic here is that employed women - those possessing marketable skills - gain further bargaining power if some of the family workload is taken off their shoulders, for example, if day care services are available. ${ }^{4}$ This is because women, even in homes where both parents work, generally undertake a disproportionate amount of both day care and household work (Cunningham, 2007; Hochschild \& Machung, 1989; Iversen \& Rosenbluth, 2010; King \& Mason, 2001, p. 169). Publicly funded day care services, therefore, allow women to take a more active part in the labour market and further invest in marketable skills, which again will further raise their economic independence and thereby also improve their bargaining power at home (Iversen \& Rosenbluth, 2010, pp. 114-115; King \& Mason, 2001). Paid leave schemes also strengthen employed women's bargaining power by making it possible for them to sustain economic independence throughout the late phases of childbearing and early phases of childrearing. They also often allow women to return to their job at the end of the leave period. The same logic also holds for employed women who are not (yet) married (or in a partnership) because these policies may become valuable to them in the future. For single mothers these policies will be of use to them right away. In sum, for women possessing marketable skills, WFPs enhance their position both at home and in the labour market. It is therefore likely that they will favour such policies to a greater extent not only than men, who do not gain bargaining power from the expansion of WFPs, but also than stay-athome women, who are mainly in possession of household-specific skills (Iversen \& Rosenbluth, 2006). Stay-at-home women's interests are quite different from those of employed women. Since they have specialized in skills employable inside the household, they have far fewer opportunities to enter the labour market in the first place. WFPs will hence be of less relevance to them; to the contrary, since these policies will involve tax increases, these women, like their husbands, will not favour such policies: they will be costly but of little use to them (Iversen \& Rosenbluth, 2010, p. 115).

An additional implication of the argument is that women who are in possession of higher education gain even more bargaining power from the introduction of day care services or well-paid leave schemes than other women, including employed women without higher education. There are at least two reasons why highly educated women should prefer WFPs more than low-skilled women.

First, the potential loss of labour market skills due to stepping out of the labour market to have children is higher for highly educated women than for those without higher education. This is because the complexity of work rises with skill level, and the

4 See, e.g., Huber and Stephens (2000, p. 334), King and Mason (2001, pp. 155-156) and Iversen and Rosenbluth (2006, pp. 12-13). 
importance of not losing contact with one's work therefore increases. In highly skilled work - such as being a manager, physician, lawyer or civil servant - both wages and career opportunities are based on previous experience, job tenure and working hours. The job market is also highly competitive. This means that an absence from the labour market to give birth and care for young children harms the career opportunities and potential wages of high-skilled women more than those of low-skilled women, which is also what the evidence indicates (Goldin \& Katz, 2011; Lundberg, 2008; Munasinghe, Reif, \& Henriques, 2008, p. 1298). As Lundberg notes, '[p]otential market wages are reduced by lost experience and job tenure due to labour force withdrawals to care for children' (Lundberg, 2008, p. 120). Because of their increased risk of absence from work due to pregnancy, childbirth and childrearing, employers are also likely to be less willing to hire and to invest in the skills of highly educated women than in those of their male counterparts (Bonoli \& Reber, 2010, p. 116; Goldin \& Katz, 2011; Konrad \& Cannings, 1997; Lundberg, 2008). For low-skilled work, on the other hand - such as being a health care assistant, salesperson or office clerk - an absence from work is not penalized to the same extent because employers are less likely to invest in these employees' skills and because the possibilities of promotions are fewer than for highly skilled work. In other words, since jobs are more routine-based and the gains from experience are lower than for highly skilled work, low-skilled women are less disadvantaged in terms of their future employment prospects when they leave the labour market to give birth and take care of their children (Munasinghe et al., 2008). Thus, the importance of WFPs - particularly day care services, which ensure the possibility of a quicker return to the labour market after childbirth - is greater for highly educated women than for women without higher education.

Second, highly educated women are more likely to be in stable, long-term employment than women without such skills (Häusermann \& Schwander, 2012). They are also more likely to return to employment after childbirth, whether or not WFPs are available (Rønsen \& Sundström, 1996). This means that highly educated women are more certain that WFPs will be of use to them since they have a greater chance of being in employment both before and after giving birth. Highly educated women will, in other words, have a higher demand for WFPs than other employed women. This should particularly be the case with maternity and parental leave since it is usually given on the basis of previous employment and earnings. Together, these reasons should lead women with higher education to demand WFPs more than other women, after controlling for income.

In addition to the gendered effect of employment and education, I also expect there to be a difference in preferences for WFPs between income groups (Meltzer \& Richard, 1981; Idema \& Rueda, 2011, p. 7). The demand is expected to decrease with income for day care services but not for leave schemes. First, as discussed, day care services are more redistributive because they are publicly funded and available to all, whereas leave schemes are largely an earnings-related transfer. Second, families and individuals with a high income can also buy day care services off the market, which 
again implies that they do not pay for more than they need. Publicly funded day care would therefore, due to progressive taxation, cost high-income individuals more than a private, market-based alternative. Moreover, the quality of publicly provided day care may be lower than the private provision, which means that high-income parents may wish to pay for a private alternative (even in the presence of a public one), and thus be paying for day care twice (through both taxation and fees). Consequently, the effect of income should be present for day care services but not for leave policies. ${ }^{5}$ Since income and education are positively correlated, this should be after the spouses' marketable skills have been taken into account.

\subsection{Empirical Analysis: Demand for Work-Family Policies}

\subsubsection{Using Cross-National Survey Data to Measure Demand}

To test the individual-level model, I will use the two International Social Survey Programme's (ISSP) surveys Family and Changing Gender Roles II and III from 1994 and 2002, respectively. These two ISSP waves ask about preferences regarding both day care services and leave policies. Data are available for 12 advanced industrialized democracies in $1994^{6}$ and 18 in 2002. ${ }^{7}$ The survey data used here only allow for 'snapshots' to be taken at two different time points (1994 and 2002), both of which occur quite late in the time period of interest. Unfortunately, I do not have surveys for earlier time periods, which would have strengthened the ability to test the individual-level theoretical model.

The two ISSP modules ask the respondents two questions that I will use to capture the demand for day care services and leave policies. The question I use to measure the demand for leave policies asks whether the respondent agrees or disagrees with the statement 'employed women should receive paid maternity leave when they have a baby'. Similarly, for day care the respondents are presented with the statement 'families should receive financial benefits for day care when both parents work'. The available answers to both questions are 'strongly agree', 'agree', 'neither agree nor disagree', 'disagree' and 'strongly disagree'. The responses to these two survey items will serve as my two dependent variables. The correlation between the two survey items is no higher than 0.47 when treating the two variables as continuous and even

5 Although, if we take into account that paid parental leave sometimes has income caps, there might also be an income effect for paid parental leave. Moreover, as I further discuss in section 4 below, in countries with high income inequality, there might also be an impact of income.

6 Australia, Austria, Canada, Germany, Ireland, Italy, Japan, New Zealand, Norway, Sweden, the United Kingdom and the United States.

7 Australia, Austria, Belgium, Denmark, Finland, France, Germany, Ireland, Japan, the Netherlands, New Zealand, Norway, Portugal, Spain, Sweden, Switzerland, the United Kingdom and the United States. 
lower when treating them as binary, with a phi-coefficient of 0.35. Since they also theoretically tap into preferences for two different policies, I analyze them separately.

For each of the dependent variables, I recode the ordinal dependent variables into binary ones. The survey respondents do not necessarily have the same understanding of the distinction between 'agree' and 'strongly agree'. The difference between 'agree' and 'disagree', in contrast, is more straightforward (see Rehm, 2011, p. 282). The variables are coded as 1 for the categories 'strongly agree' and 'agree' and 0 for the categories 'neither agree nor disagree', 'disagree' and 'strongly disagree'. 'Do not know' is treated as zero to avoid conditioning on an endogenous variable.

Neither of these two survey items, regrettably, fully captures the demand. The latter question neither directly asks about day care services that are publicly funded and fulltime nor mentions the potential tax increase following the introduction of this costly public service. More specifically, the question does not ask whether the respondents prefer a full-time or a part-time service. Yet there is an important difference between the two: a full-time service would allow employed mothers to more wholly take part in paid work and develop their skills and positioning in the labour market than would a part-time service. Moreover, the question asks about day care benefits rather than day care services. As emphasized in the section on the conceptualization of WFPs, services are usually more redistributive than transfers. The question hence does little to pick up the theorized redistributive conflict over WFPs between the higher and lower income groups. In sum, the question I use to capture the demand for day care services seems to understate the redistribution between income groups, and it does not say whether the policy would make it possible for women with young children to maintain their economic independence. This means that the effects of education and employment on this dependent variable are likely to be attenuated compared to a more ideal survey question asking about publicly funded, full-time day care services.

The question concerning maternity leave does not ask whether the respondents are in favour of parental leave as well as maternity leave. Because it might be easier, and less costly in terms of taxes, to agree that employed women should be compensated for an absence from work because of childbirth than to agree that parents should receive benefits for a longer period of time after the child is born, this survey item is not ideal for capturing the preferences for leave policies. Furthermore, the survey item fails to ask whether the respondents favour a maternity leave that fully replaces employed women's income and does not mention the length of the leave. Both respondents who believe that employed women should be entitled to a long and well-paid leave and those who believe that they should only be entitled to a short and poorly paid one would be able to agree fully with the survey question. Yet a benefit that provides a full replacement of their previous salary would facilitate employed women's financial independence and enhance their bargaining power more than a less generous one. The question consequently allows us to tap into the potential conflicts over leave policies only to a limited extent. I therefore expect even less effect of my main explanatory variables for the maternity leave than the day care question. 
Still, it seems plausible that respondents who agree with the survey item about day care benefits also favour publicly funded day care services and that agreeing with the item about maternity leave is correlated with being in favour of well-paid maternity and parental leave. Using these data also improves earlier tests of bargaining models for explaining social policy preferences. Whereas earlier studies by Iversen and Rosenbluth use survey items for preferences regarding public employment to test whether there is a gender gap in social policy preferences, the survey questions allow us to directly capture the preferences for WFPs (Iversen \& Rosenbluth, 2006, 2010). The analysis here thus provides a more precise test of a bargaining theory than earlier analyses. Moreover, the individual-level theory in this chapter differs from Iversen and Rosenbluth in that I emphasize the role of higher education.

\subsubsection{Measuring Employment and Education in the Survey Data}

I now turn to the explanatory variables. My first hypothesis is that women who are employed full-time are more likely to demand WFPs than men in full-time employment and women who are stay-at-home because WFPs increase employed women's economic independence and their position in the labour market by making it possible for them to combine a career with having children. I include full-time employed as a dummy variable taking the value 1 if the respondent is employed fulltime and interact this variable with the gender variable. In addition, I include a set of dummy variables to control for other employment categories so that I compare working full-time to being stay-at-home. ${ }^{8}$

Figure 15.1 shows the proportion of respondents favouring day care and maternity leave by employment status and sex for the 1994 and 2002 surveys combined. Each of the two dependent variables are coded into binary variables, taking the value 1 if the respondent strongly agrees or agrees with the survey question and 0 otherwise. Although Figure 15.1 can only serve as impressionistic evidence, several interesting patterns emerge. As hypothesized, stay-at-home women are less in favour of day care benefits and maternity leave than full-time employed women. There is little difference between the employment groups for men, and full-time employed women are more likely than full-time employed men to favour these WFPs. Note that there are very few stay-at-home men in the sample used in this analysis: only about 1 percent of the sample in 1994 and 1.5 per cent in 2002 are stay-at-home men. This category is thus

8 The other dummy variables that serve as controls are thus: part-time employed, unemployed, student/vocational training, retired and others, which includes respondents who are permanently disabled or ill, helping family members or not in the labour force. Every respondent is a 'member' of one and only one of the dummy variables. 
more or less negligible. Stay-at-home women, on the other hand, make up 25 percent of the sample in 1994 and 18 percent of the sample in 2002. ${ }^{9}$
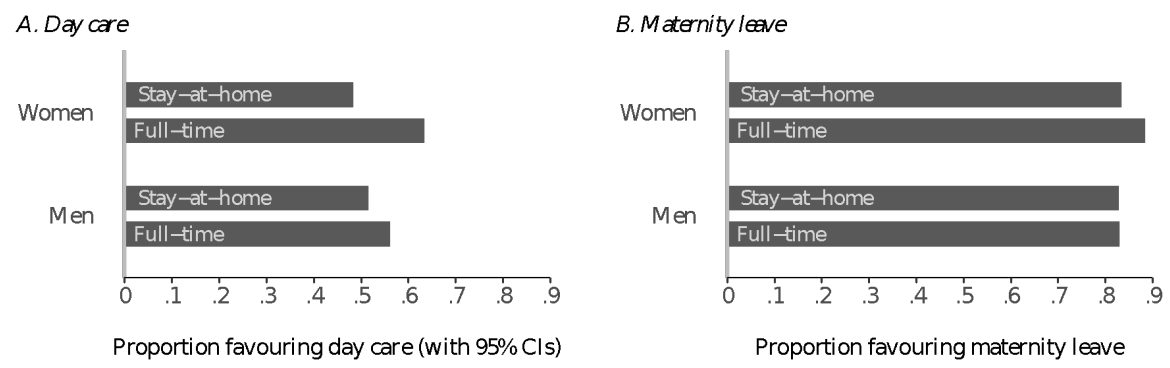

Figure 15.1. Proportion of respondents favouring day care and maternity leave by employment status and gender

My second hypothesis is that highly educated women have a higher demand for WFPs than other women but also than highly educated men. This is because they are often in stable employment requiring high-level skills so that leaving the labour market to have children would damage their career prospects more than it would for women without higher education. What I want to capture with the measure is thus a distinction between respondents with higher education - the highly skilled - and those without - the low-skilled. I operationalize being highly educated as having completed a university degree. I then interact this binary variable with gender, where I expect higher education to have an effect for women but not for men. Modernization theorists have also included education as one of their explanatory variables. These researchers, notably Inglehart and Norris, see norms of gender equality, and preferences for social policies promoting gender equality, as a result of the changes in culture associated with economic growth, the shift towards postindustrial societies and intergenerational replacement (Inglehart \& Norris, 2000, 2003). Still, their predictions about the effect of education differ from my theory. Inglehart and Norris hypothesize that 'postmodern values of gender equality will be most evident among the secure, that is, the wealthier, better-educated sectors of the public' (Inglehart \& Norris, 2003, p. 18) and that women favour gender equality more than men (Inglehart \& Norris, 2003, p. 19). They thus predict that the highly educated women and men should be more positive towards WFPs. Household bargaining theory instead predicts that education has an effect only for women; we should not see any difference between men with high and low education levels because WFPs do not enhance their

9 Note also that the support among employed men is surprisingly high. Further understanding of when men favour WFPs is hence an avenue for future research. 
bargaining power. Moreover, I have argued that income should have a negative effect on the demand for WFPs, whereas Inglehart and Norris seem to suggest that the effect of income should be positive. I should consequently be able to say whether the results presented below lend more support to one theory or the other.

We can get a first impression of the differences between preferences from Figure 15.2. For both day care and maternity leave we see that there is almost no difference between men with and without a university degree; however, among women, a higher proportion of those with a university degree than those without favour day care and maternity leave. This is consistent with the theoretical argument.

My third hypothesis is that there are income differences for day care but not for parental leave policies. Income is included as a set of dummy variables corresponding to the bottom third, the middle third and the top third of the household income distribution in a given country in a given year.

To ensure that the associations between demand for WFPs and education, employment and income, respectively, are not due to differences in religion (measured as church attendance), the number of dependents, cohort or the spouse's employment status, I include these as control variables. ${ }^{10}$
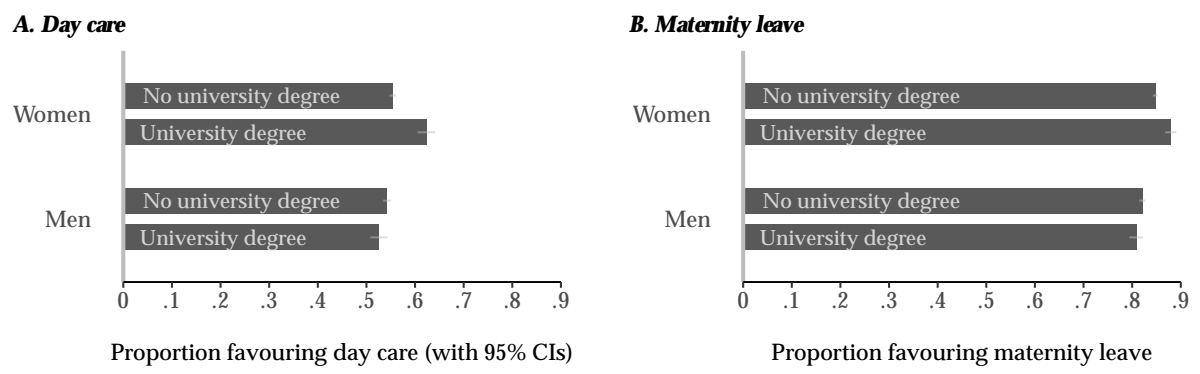

Figure 15.2. Proportion of respondents favouring day care and maternity leave by education and gender

10 Religion is measured as the frequency of church attendance. It ranges from 0 to 5 , where 0 is never, 1 is about once a year, 2 is several times a year, 3 is once a month, 4 is $2-3$ times a month and 5 is once a week or more. It is treated as continuous. Dependents and cohort are included as sets of dummy variables. The spouse's employment status is measured in the same way as the employment variable described above. It is interacted with the dummy for gender. Descriptive statistics for all of the independent variables are given in Table A-1 in the Appendix. 


\subsubsection{Evidence of Gender Differences in Demand for Work-Family Policies}

The goal in this section is to test whether there is an association between demand for WFPs and employment, education and income, respectively - in other words, to look at the individual-level factors (in the next section, I look closer at cross-national, institutional differences). To obtain estimates of these associations across all countries, I pool together the data for all countries and both the 1994 and 2002 waves and analyze them using a linear probability model. ${ }^{11}$

I focus on central predictions from these models, which are displayed in Figure 15.3, leaving the technicalities to the footnotes. ${ }^{12}$ The figure has four panels, in which the bars show changes in how likely individuals with different gender, education and employment status are to demand day care and parental leave. The thin line segments give the uncertainty surrounding these estimates (95 percent confidence intervals). As a rule of thumb, if the intervals overlap with zero, we cannot rule out that there is no relationship between demand for WFPs and the different categories of gender, education and employment.

Panels A and B deal with the demand for day care. In Panel A, the upper bar shows that highly educated women are 7.6 percentage points more likely to agree that dual-earner families should receive day care benefits compared to low-educated women. Among men, on the other hand, only one percentage point separates the high- from the low-educated, and the difference is far from statistically significant. Education is thus an important predictor of WFP demand for women but not for men, which is what the household bargaining framework would predict. We can illustrate this effect with the following example. In Sweden, in 2002, 19.9 percent of women over the age of 25 had completed a university degree, whereas in Italy the number was

11 First, compared to a logit or probit model, the linear probability model has the advantage that the coefficients are directly interpretable as probabilities. Moreover, since all the key variables are binary variables, predictions below the probability of 0 and above the probability of 1 are not an issue (Angrist \& Pischke, 2009). All the results presented in this chapter are quantitatively and qualitatively highly similar if we instead use a logit or probit model. Second, to control for cross-national differences and for differences over time, I include a full set of country dummies and time dummies. I also include the set of control variables discussed above. The robust standard errors are clustered by country-survey year.

12 The figure gives the percentage point change in the predicted probability of favouring day care and maternity leave, respectively. To compute predicted probabilities, I use the regression estimates from models 4 and 8 in Table A-2 in the Appendix. To ensure that the predicted probabilities are generalizable to the whole population of the countries and time periods I am investigating, I hold the other variables in the model at their observed values (see Hanmer \& Ozan Kalkan, 2012). Moreover, to evaluate the statistical and substantive significance of an interaction (between for instance education and gender) we need to look at the second difference. The $\mathrm{p}$-value for the second difference is the $\mathrm{p}$ value given in each of the panels. 

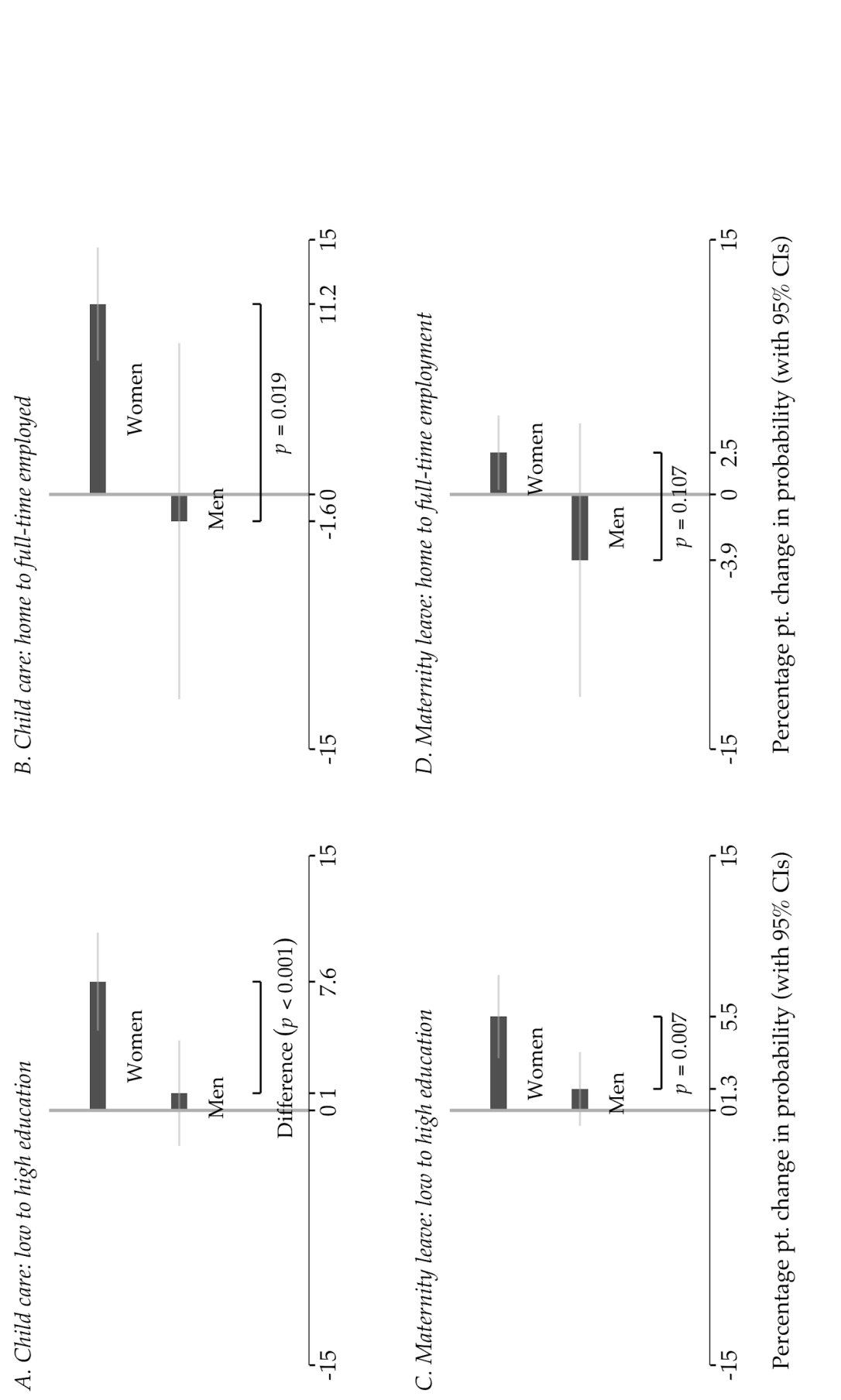

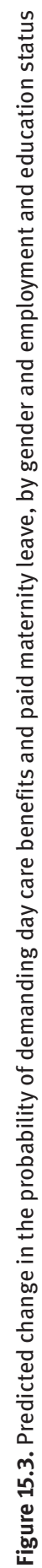


6.4 (Barro \& Lee, 2010). The results thus imply that, for 13.5 percent of the women, ${ }^{13}$ their chance of supporting day care is predicted to be 7.6 percentage points higher in Sweden. Given the importance of highly educated women as an electorate for political parties, this should have clear effects on the policies pursued, and more so in Sweden than in Italy (Morgan, 2012, 2013).

In Panel B, I have predicted the difference in day care demand for stay-at-home and full-time employed among women and men, respectively. The same pattern as for education emerges here. Full-time women are 11.2 percentage points more likely to say that they favour day care benefits than stay-at-home women. For men, there is no such difference. Moreover, this comparison makes less sense, as there are strikingly few stay-at-home men in our sample (only one per cent of men, compared to 21 percent of women).

If we add the findings from panels A and B together, we can see that women who are highly educated and working full-time are predicted to be almost 19 percentage points more likely to demand day care than women who are low-educated and stay-at-home. This is a considerable difference in the demand for WFPs. What is more, in contrast to Inglehart and Norris's modernization theory (Inglehart \& Norris, 2000, 2003), which would predict that the highly educated (and full-time employed) are more positive towards policies promoting gender equality, I argued that higher education should only have an effect for women because these policies strengthen only their position in the labour market and bargaining power, and not highly educated men's position. The results seem to be more in line with the argument made in this chapter than the claims made by Inglehart and Norris.

Finally, in panels C and D, I look at the demand for leave. Although the results are more attenuated here, they mirror those for day care. ${ }^{14}$ Employed and highly educated women are more likely to demand paid maternity leave than both men and stay-athome women.

We might, for instance, be concerned that these differences between, for instance, high- and low-educated women are due to the fact that low-educated women have more children. Note, however, that these differences between high- and low-educated and full-time employed and stay-at-home women and men cannot be due to differences in the number of children, religiosity, the spouse's employment status, age, cohort or household income as I hold these factors constant. Of course, we cannot guard against the worry that there might be other factors that make some women more likely to both have high education and demand WFPs. Nevertheless,

13 I.e. $19.9-6.4=13.5$

14 More than 80 per cent of the respondents either strongly agree or agree with the maternity leave survey item. When I use an ordered logit model and examine the predicted probabilities of strongly agreeing, the effects for maternity leave are considerably greater (results not shown). 
the results indicate that there are at least clear associations between education and employment and demand for WFPs for women but not men.

In addition to the importance of employment and educational resources, I argued that income should decrease the demand for day care services but not paid leave as the former is redistributive, whereas the latter is not. Figure 15.4 depicts the changes in predicted probabilities of demanding day care and maternity leave between low and middle income and low and high income. When moving from low to high income - that is, from the bottom to the top third of the income distribution - the predicted probability of favouring day care benefits decreases by 4.1 percentage points. For maternity leave, on the other hand, the probabilities are close to zero and the confidence intervals overlap with zero. Thus, for maternity leave, the income effect is either absent or very weak. These results - the negative effect of income on day care and the absence of such an effect on leave schemes - provide support for the argument that there is a redistributive aspect to day care services but not to leave policies.
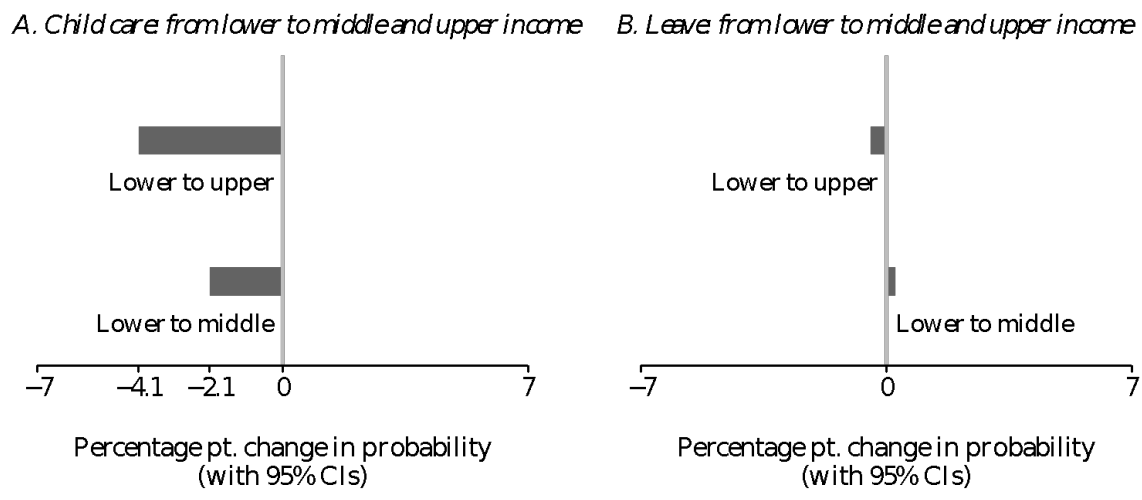

Figure 15.4. Predicted change in the probability of demanding day care benefits and paid maternity leave by income tertiles

\subsection{Institutional Variation in Demand}

\subsubsection{Work-Family Policies, Skill Specificity and Wage Inequality}

Individuals' resources are not the only source of support for WFPs. A growing body of work suggests that the structure of a country's labour market and welfare state institutions affects citizens' support for the welfare state and redistributive policies (see e.g., Cavaillé, 2014, 2015; Gingrich, 2014; Gingrich \& Ansell, 2012). In this section, 
I will explore several ways in which national-level social institutions may affect individuals' demand for WFPs.

First, there are reasons to believe that there is a two-way relationship between work-family policies themselves and the demand for such policies. The popular demand for social policies is typically seen as a key incentive for governments to introduce and expand welfare programmes (Brooks \& Manza, 2007; Huber \& Stephens, 2000; Morgan, 2012; Rehm, 2011). When these programmes are implemented they can, additionally, create (positive) feedback effects, as Pierson's work nicely illustrates (Pierson, 1996, 2000). There is a possibility that once day care services and parental leave have been introduced, and parents have started realizing their benefits, these individuals will increase their support and demand for these welfare policies as well as oppose any downsizing of the programmes. Thus, once created, these policies become 'sticky' due to popular support. The possible two-way relationship leads us to expect that support for WFPs is higher in countries with more extensive WFPs.

Second, long-existing labour market institutions may also create differences in policy support. One reason is the types of skills that firms make use of in different economies. Compared to the Anglo-Saxon and Irish liberal market economies, firms in the coordinated market economies of Germany and the Nordic countries make more use of skills learnt on the job and that are not applicable outside a particular industry or firm (Estévez-Abe, Iversen, \& Soskice, 2001; Thelen, 2004). This variation in skill specificity is reinforced by trade unions and employers' associations and their collective bargaining institutions (Iversen \& Rosenbluth, 2010, p. 112). EstévezAbe (2005) and Iversen and Rosenbluth $(2006,2010)$ argue that women in countries that rely more heavily on industry- or firm-specific skills in production should be particularly likely to demand WFPs. The reason is that specific skills are mostly acquired through on-the-job training, where women are at a disadvantage due to family-related work absences (see also Estévez-Abe, 2006). The presence of day care services may alleviate such a disadvantage and make it easier for women to invest in (specific) labour market skills and thus increase their outside options. ${ }^{15}$ Women in more skill-specific countries should thus be more likely to demand WFPs.

Third, above we saw that higher income was associated with lower demand for day care but not leave. Yet, wage inequality in the overall society - which is on the rise in many advanced industrialized democracies (Autor, 2014; Iversen \& Soskice, 2015; Piketty, 2013) - might also influence the demand for WFPs. As Iversen and Rosenbluth (2010, p. 141) succinctly write about the demand for day care, 'women at the top of the income ladder have at their disposal private sector alternatives often supplied by low-paid female workers - to tax-funded child care and other

15 Long parental leave periods may play the opposite role as they increase mothers' time away from employment (Estévez-Abe, 2006). Short leave periods, however, may make women less likely to drop out of the labour force altogether (Thevenon \& Solaz, 2013). 
services'. This is particularly the case in countries with high wage inequality, where child care is less expensive for top income earners compared to their counterparts in countries with low wage inequality. With smaller wage differences, child care is relatively more expensive for middle and top income earners. The implication is that as wage inequality increases and private day care options become relatively cheaper, there should be less demand for public, tax-funded day care solutions, particularly from middle and top income earners. A similar logic might be applied to paid parental leave. In high income inequality countries, high income earners are more likely to have company-paid parental leave, which reduces the need for a tax-funded public parental leave scheme. Wage inequality could, in other words, be negatively associated with demand for WFPs.

\subsubsection{Empirical Patterns of National Institutions and Demand for WFPs}

I explore these conjectures about the effects of WFPs, skill specificity and wage inequality by examining how these factors co-vary with the country-level variation in the support for WFPs. I use the same data as in the individual-level analysis. More precisely, I calculate the percentage support for WFPs in a given country in 1994 and 2002, after controlling for the individual-level variables. ${ }^{16}$ I then correlate these predicted probabilities with the institutional country-level variables. ${ }^{17}$ First, however, I will describe the data and show how the institutional variables cluster across countries.

The macro-level variables are measured as follows. Day care services are operationalized as the public spending on day care and home-help services per child under school age (given in constant 2000 US dollars PPPs), with data on day care spending from the OECD (2012b) and data on the age at which children start school and the number of children under the relevant age from the World Bank (2012). Parental leave generosity is measured as the number of weeks of parental leave available multiplied by the wage replacement rate. For instance, if 20 weeks of parental leave are available with a wage replacement rate of 75 percent, then the leave generosity variable takes the value of 15 (for a similar operationalization, see Akgunduz \& Plantenga, 2012). The skill specificity measure is a variable taking the mean of (i) the vocational training share and (ii) the median length of tenure in a country after these two variables have been standardized to have a mean of zero and a standard deviation of one (Iversen, 2005; Iversen \& Rosenbluth, 2006, 2010). The data

16 I use the survey-year-by-country fixed effects included in the linear probability model, which give the predicted probabilities of favouring day care and leave (for each country-year).

17 The results using a Bayesian multilevel model strategy are highly similar and lead to the same conclusions as those presented here. The multilevel results are available from the author. 
are from Iversen (2005, p. 55, Table 2.6). Income inequality is measured using the Gini coefficient calculated from individuals' net income - see Solt (2009) for details on the measurement and the data.

WFP generosity, skill specificity and income inequality form part of the institutional clusters, or varieties of capitalism, found across countries (see Iversen \& Rosenbluth, 2006, 2010; Iversen \& Soskice, n.d.). The Nordic coordinated market economies (CMEs) typically have high investment in WFPs, high skill specificity and low income inequality. The Continental CMEs are close to the Nordic CMEs but have lower investment in WFPs and somewhat higher levels of income inequality. In the liberal market economies (LMEs) of the Anglo-Saxon and Irish world, we see the flip side of the Nordic CMEs. As expected, if we conduct a simple cluster analysis based on both the institutional variables and the support for day care services and paid leave, these clusters of countries are reflected in the data. ${ }^{18}$ Since I have only continuous variables, I use Ward's linkage with the squared Euclidean distance measure to derive clusters of countries. ${ }^{19}$ Figure 15.5 provides evidence that, in a twocluster solution, which is illustrated with the dotted rectangle, the cluster analysis divides the countries neatly into LMEs and CMEs. What is more, in a three-cluster solution, which is illustrated with the grey rectangle, the cluster analysis finds that the CME group should be split into Nordic and Continental CMEs (with the exception of Austria, which is classified as a Nordic CME). We can thus think of the institutional variables as capturing different aspects of broad labour market and welfare state regimes (Esping-Andersen, 1990; Hall \& Soskice, 2001).

As a first cut, we can examine whether the demand for WFPs varies between the two broad LME and CME clusters. In Figure 15.6, I plot the support for WFPs for each country-year along with the cross-country mean for LMEs and CMEs, respectively. We see that the demand for both day care and leave is, on average, higher in CMEs than in LMEs, which is what the institutional hypotheses above would lead us to expect. There is, nevertheless, large variation within the clusters, and the same holds if we would make similar plots for the institutional variables. ${ }^{20}$

18 Broadly speaking, cluster analysis groups observations so that it maximizes the similarities within the cluster and at the same time maximizes the dissimilarities between the clusters in terms of the variables used in the cluster analysis (for details, see, for instance, Bartholomew, Steele, Moustaki, \& Galbraith, 2008).

19 According to Bartholomew et al. (2008, p. 24), Ward's method 'in practice...often seems to yield the clearest picture of any clustering which is present'.

20 Moreover, in my sample, the correlations between the national variables are 0.51 (between day care services and parental leave), 0.31 (day care services and skill specificity), - 0.66 (day care services and income inequality), 0.56 (parental leave and skill specificity), -0.67 (parental leave and income inequality) and -0.62 (skill specificity and income inequality). 


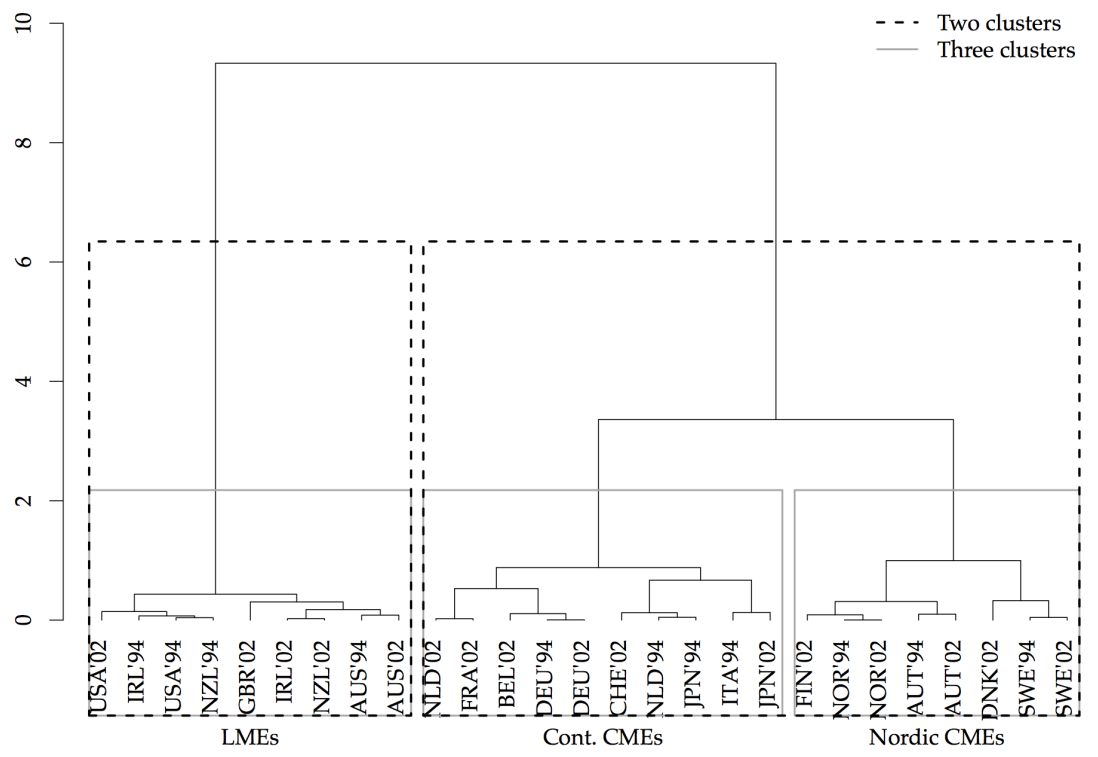

Figure 15.5. Clustering of countries using Ward's method with the squared Euclidean distance measure and variables standardized to vary between 0 and 1

\section{A. Demand for day care}

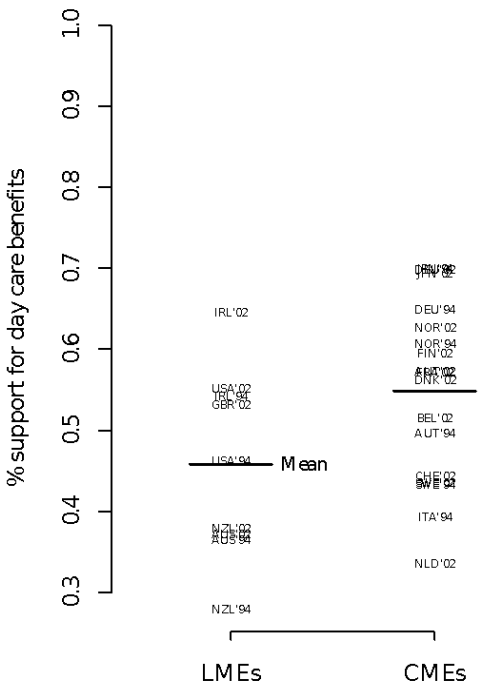

Cluster

\section{B. Demand for leave}

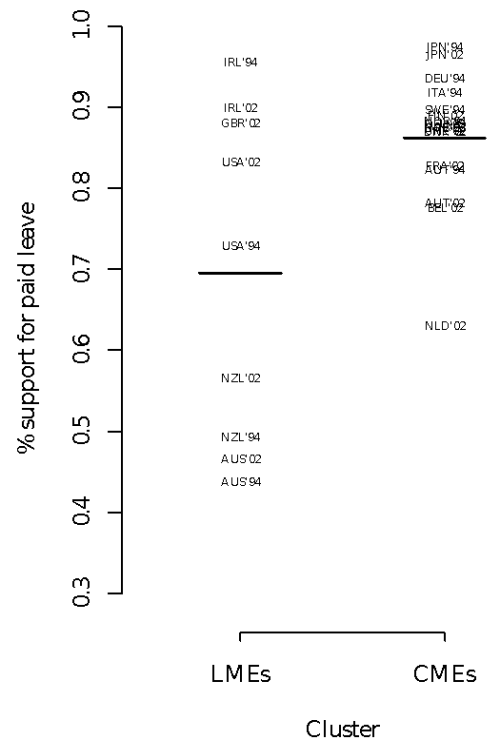

Figure 15.6. The mean and distribution of country-level support for day care and paid leave across liberal market economies (LMEs) and coordinated market economies (CMEs) 
We can consequently be more precise about which of the institutional features are particularly associated with higher support for WFPs at the country level and thus which of the institutional hypotheses presented in the previous section receive support. To do so, I present a series of simple bivariate plots correlating WFP generosity, skill specificity and income inequality with support for day care services and parental leave. The results are illustrated in Figure 15.7, where Panel A displays the findings for day care services and Panel B for paid leave. In each of the graphs, the $y$-axis shows the national-level independent variable, and the $x$-axis shows the predicted support for day care and leave for each country-year. For instance, in the first graph in Panel A, 'DK '02' gives the day care spending ( $x$-axis) and level of day care support ( $y$-axis) for Denmark in 2002. The graphs also include a grey ordinary least squares (OLS) regression line for the association between the two variables. Remember that when calculating the country-level average support for the WFPs, I have controlled for the individual-level variables analyzed in the previous section.

We can first look at the association between the provision of day care services and parental leave, on one hand, and the associated demand for day care and parental leave, on the other. The first graph in panels A and B depicts these associations. For day care services, the results indicate that there is no association between provision and demand. The grey regression line is flat. For parental leave, however, the findings suggest that there is a clear and statistically significant correlation between having a more generous paid parental leave scheme and the support for such a policy. For instance, going from the United States to Sweden in terms of paid parental leave in 1994 - that is from zero to 44.6 weeks of fully paid leave - is associated with having an 18 percentage points higher average support for paid maternity leave. This is a sizable effect. Of course, the results for leave schemes cannot say anything about the direction of causality or whether the relationship is spurious. These results are, nevertheless, at least in line with the arguments that social policies reflect the public demand for them and that the instigation of such policies again creates public support for WFPs.

Next, we can examine the relationship between skill specificity and support for day care services and maternity leave. The results are shown in the second graphs in panels A and B. For both of these WFPs, countries with higher levels of skill specificity have a higher average demand for WFPs. To illustrate the findings, we can again use the 1994 US-Sweden comparison. Going from the US to Sweden in terms of skill specificity - that is, to a higher incidence of vocational training and longer average job tenure rates - is predicted to be associated with a nine percentage points higher support for day care services and 15 percentage points higher support for paid leave. In line with Iversen and Rosenbluth (2010) there is thus some evidence that skill specificity is associated with higher demand for WFPs. ${ }^{21}$

21 In contrast to the skill-specificity thesis, however, women and men in skill-specific countries demand more WFPs than in general skill countries (results available upon request). 

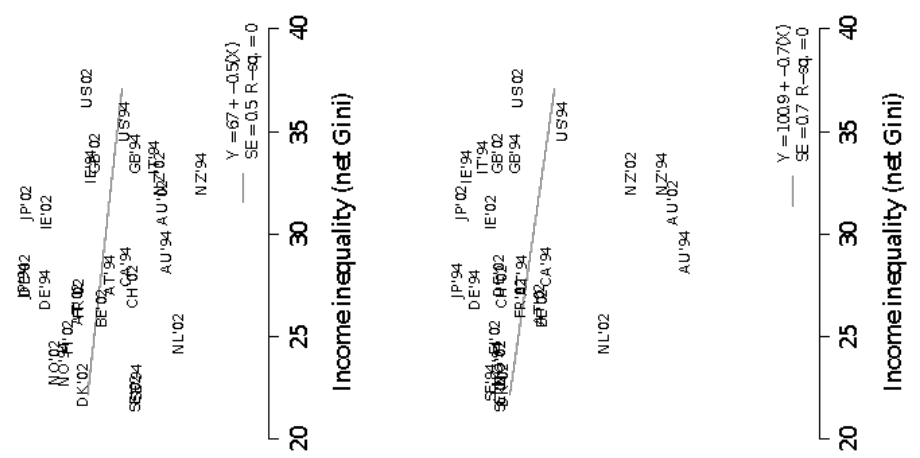

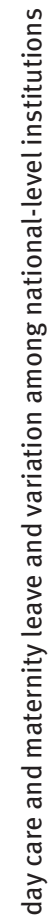
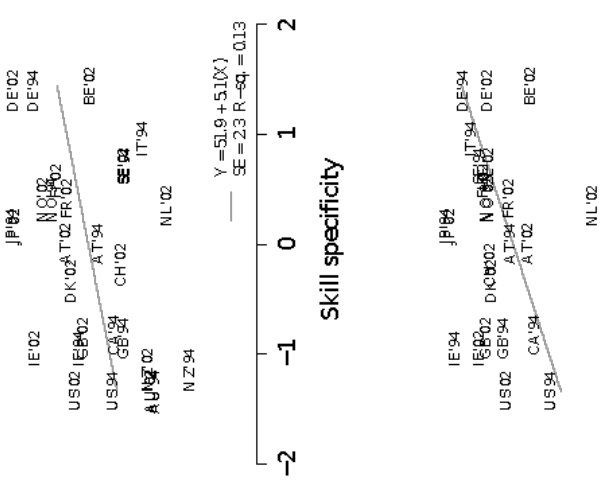

竞

然

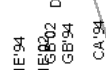

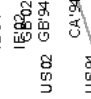

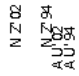
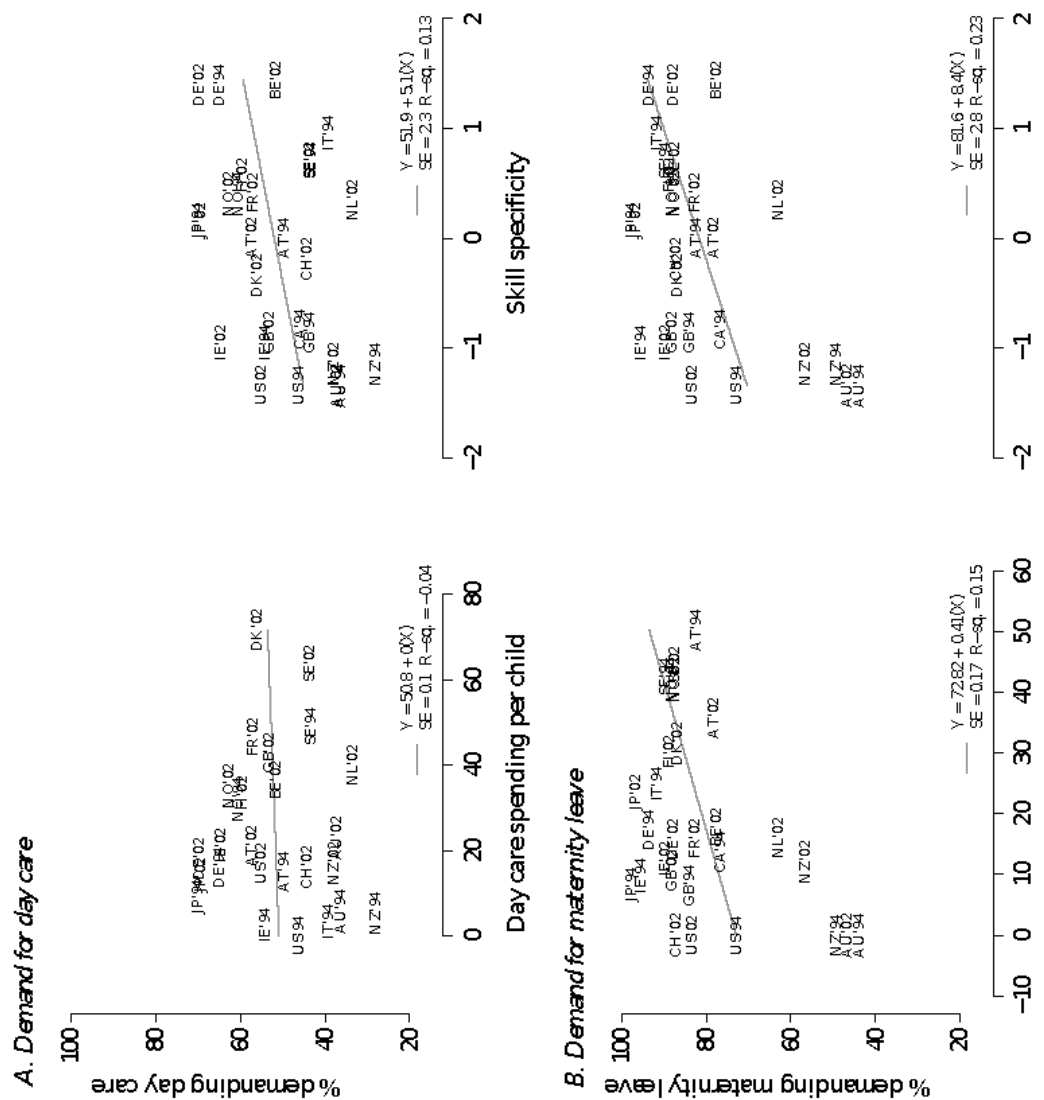

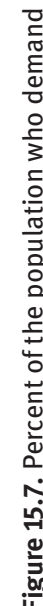


Finally, we can have a look at the wage inequality hypothesis. As the third graphs in panels A and B indicate, there is a slightly negative correlation between income inequality and country-level support for WFPs. This is consistent with the argument that as wage inequality rises, there is less demand from middle and upper classes for publicly funded day care services. That said, with standard errors that are of the same size as the coefficients, these results are far from statistically significant.

Yet, we can also explore the income inequality hypothesis in a more detailed fashion. If we follow the logic of the argument, then the difference between the poor and the rich in demand for WFPs should be larger in high-inequality than lowinequality countries. Figure 15.8 explores this implication empirically. In the same way as Figure 15.4 in the previous section, the $y$-axis here provides the change in support for WFPs when we go from low- to high-income individuals in each of the country-years. In the US in 1994, for instance, individuals in the top income group were 12 percentage point less likely to support day care compared to individuals in the low income group. As we can see from the graphs, both for day care services and paid leave there is a tendency for the gap in demand between low- and upper-income groups to widen with increasing income inequality. Even though these results are highly suggestive, they are at least concordant with the wage inequality hypothesis.

In sum, the empirical institutional analysis in this section provides some indicative evidence in favour of the policy feedback hypothesis, somewhat clearer support for the skill specificity argument and some evidence supporting the wage inequality prediction.
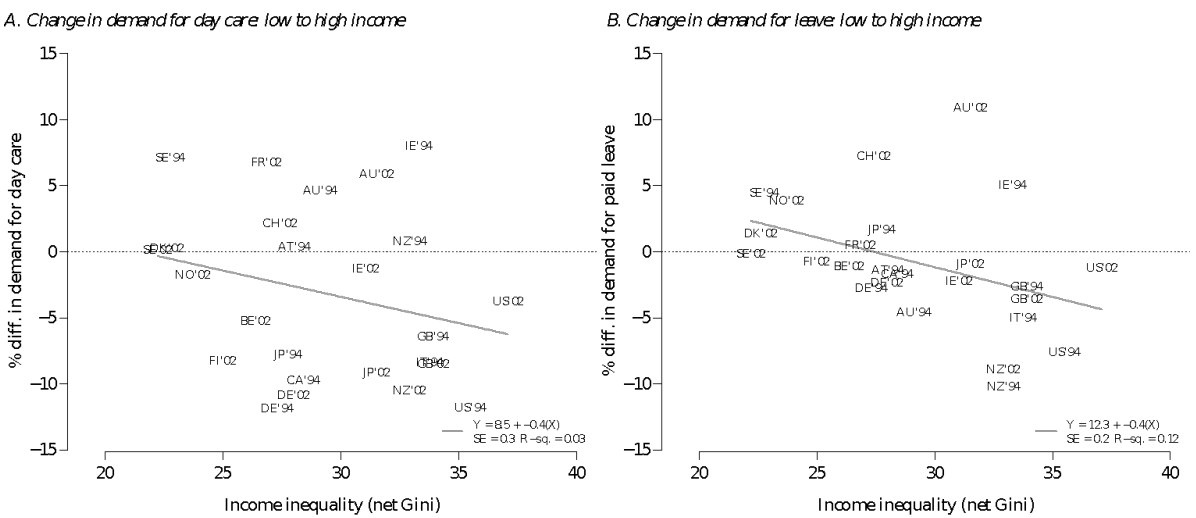

Figure 15.8. The change in the probability of favouring day care and paid leave when going from low to high income individuals for each country for each survey year 


\subsection{Conclusions and Political Implications}

Over the last 40 years, work-family policies (WFPs) have become an increasingly important part of most advanced welfare states. Understanding the expansion of WFPs is therefore necessary to understand the changing nature of welfare states at large. Nevertheless, the existing literature on WFPs remains inconclusive concerning which groups of voters demand WFPs. The aim of this chapter has been to take the first steps towards addressing these shortcomings by undertaking an analysis of voter demand for day care services and paid parental leave policies.

To explain which voters demand WFPs, I drew on the literature on household bargaining, which takes seriously the power relations within the family institution. I argued that both employed and highly educated women demand WFPs more than other voters. Employed women demand WFPs because such policies will strengthen their economic independence and make it possible for them to take a more active part in the labour market, which will increase their bargaining position at home. Highly educated women demand WFPs even more because their absence from work due to childbirth harms their potential wages and career opportunities more than is the case for employed women doing low-skilled work. Moreover, day care services, due to being available to all with means-tested payments, are more redistributive than leave policies, which are positively related to previous earnings. This means that whereas upper-income voters would demand day care services to a lesser extent than lowincome ones, this is not the case for leave policies.

In the empirical analysis, I used the ISSP 1994 and 2002 surveys to test my argument about individuals' demand for day care services and leave policies on samples of 12 and 18 advanced industrialized democracies. In a series of regression analyses, I found support for my contentions regarding the demand from both employed and highly educated women and that low-income individuals have a higher demand for day care services but that there is little effect of income for leave policies. The results confirmed the viability of using a bargaining framework to explain individuals' preferences for WFPs. In addition, I showed that, even after we account for individual-level differences in demand, national-level institutions - in particular the degree to which a country relies on specific skills, the existing level of WFPs and the level of income inequality - also correlate with the cross-national variation in demand for WFPs.

The findings may have important implications for understanding the extent to which the need for WFPs is met with political supply of such policies. Given that employment and education rates among women, as well as the number of dual-earner couples, are rising, there are reasons to believe that the need for WFPs is becoming crucial for an increasing share of the population. Still, the question remains whether political parties have incentives to listen to this demand.

The analysis in this chapter provides some evidence that the gender revolution in tertiary education is likely to turn the growing number of middle-income, highly 
educated women - who favour WFPs more than both other middle-income voters and other employed women - into an increasingly important group of voters for parties to attract (Fleckenstein et al., 2011; Morgan, 2012). With increasing education rates among women, parties thus begin to face a tradeoff between favouring a (growing) constituency of highly educated women or a (declining) constituency of stay-at-home women and their spouses.

Still, due to their different redistributive implications, the political logic may differ for day care services and leave policies. Regarding day care services, left-leaning governments may be more responsive to the demand from highly educated women than right-leaning governments. This is because day care services are redistributive, which means that low-income, highly educated women have a higher demand for day care services than those with a high income. Moreover, leftist parties' ideology related to income equality, as well as to the legacy of expansion of redistributive welfare policies, means that the redistributive aspect of day care services, and the implied further expansion of the public sector, is seen as a benefit rather than a problem to them (Huber \& Stephens, 2001). For right-wing parties, the logic is different. Since upper-income, highly educated women are more likely to be able to buy day care services in the market, they demand day care services less than those with a low or middle income. Right-wing parties consequently have fewer incentives to enact day care services than left-wing parties. Yet, with increases in the number of middleincome, highly educated women, they may still have to do so in order to not lose these swing voters to left-wing parties. They may, however, instigate WFPs more reluctantly than left-wing parties. Regarding leave policies, parties both to the left and right may be equally responsive to the demands from a growing number of highly educated women. This is because leave schemes preserve income differentials and because, as a transfer, they do not require an increase in the size of the public service sector. This also brings this policy more in line with the preferences of high-income voters and right-wing parties' ideologies. Taken together, there are reasons to believe that leftwing and eventually right-wing parties will turn around and become more responsive to the WFP demands from highly educated women.

Parties may, however, have fewer incentives to be responsive to the demands from low-skilled employed women, who typically are labour market outsiders. ${ }^{22}$ First, outsiders, including female ones, are less likely to vote than insiders (Häusermann \& Schwander, 2012; Rueda, 2007). Second, female outsiders usually find themselves at the bottom of the income scale, which means that they are foremost potential voters for leftist parties. Consequently, they are, in contrast to highly skilled women, not only less likely to vote but also not to be swing voters whom both left-wing and

22 The term 'outsiders' refers to individuals who are unemployed or in precarious employment, such as involuntary fixed-term and part-time work with low employment protection. 'Insiders' refers to individuals in standard secure employment. 
right-wing parties compete with each other to attract. Parties may therefore be less responsive to their demands, which is concerning from a democratic point of view. Indeed, it might be that it is only when female outsiders' demand for WFPs coincides with that from highly educated women that the former will get the policies they want and need. But the reason for WFP expansion then stems from the demand from highly skilled women and not from female outsiders. If this logic is correct, then it draws up a disturbing picture: in countries that are witnessing rising female labour force participation rates but where most of these women are low-skilled, such as in Italy and Spain, women's struggle to balance their paid work, child care responsibilities and household work may not be adequately addressed by political parties. Although WFPs can address gender inequities in the labour market, they are thus likely to be lacking where they are needed the most.

To wrap up, this paper has aimed to make two contributions to the scholarly literature. First, to my knowledge, all studies of welfare policies that have sought to include demand from employed women as an independent variable have used female labour force participation as a proxy for demand. None of these studies has discussed the demand from highly educated women or tested for it in their empirical models. Yet, the results suggest that the demand by highly educated women might be an important driver of the increases in WFP generosity. Future investigations of WFPs and other welfare policies with gendered implications should thus include the demand by women with higher education in their analyses. Second, with WFPs becoming more prominent in countries' provision of social policies, my findings contribute towards our understanding of the changing nature of the welfare state. I showed how theorizing and investigating the demand for WFPs may provide a viable starting point for grasping the ongoing transformation of welfare states and public policies.

\section{References}

Akgunduz, Y. E., \& Plantenga, J. (2012). Labour market effects of parental leave in europe. Cambridge Journal of Economics, online early access, November 23, 2012.

Albanesi, S., \& Olivetti, C. (2007). Gender roles and technological progress. National Bureau of Economic Research Working Paper Series, No. 13179.

Allan, J. P., \& Scruggs, L. (2004). Political partisanship and welfare state reform in advanced industrial societies. American Journal of Political Science, 48, 496-512.

Angrist, J. D., \& Pischke, J. (2009). Mostly harmless econometrics: An empiricist's companion. Princeton, N.J.: Princeton University Press.

Autor, D. H. (2014). Skills, education, and the rise of earnings inequality among the 'other 99 percent'. Science, 344(6186), 843-851.

Barro, R., \& Lee, J. (2010). A new data set of educational attainment in the world, 1950-2010. National Bureau of Economic Research; NBER Working Paper No. 15902.

Bartholomew, D. J., Steele, F., Moustaki, I., \& Galbraith, J. I. (2008). Analysis of multivariate social science data (2nd ed.). London, U.K.: CRC Press. 
Becker, G. S. (1981). A treatise on the family. Cambridge, U.K.: Harvard University Press.

Berrington, A., Hu, Y. J., Smith, P. W. F., \& Sturgis, P. (2008). A graphical chain model for reciprocal relationships between women's gender role attitudes and labour force participation. Journal of the Royal Statistical Society Series a-Statistics in Society, 171, 89-108.

Blau, F. D., Ferber, M. A., \& Winkler, A. E. (2010). The economics of women, men and work (6th ed.). Boston: Prentice Hall.

Bonoli, G., \& Reber, F. (2010). The political economy of childcare in OECD countries: Explaining crossnational variation in spending and coverage rates. European Journal of Political Research, 49(1), 97-118.

Brooks, C., \& Manza, J. (2007). Why welfare states persist: The importance of public opinion in democracies. Chicago, Ill.: University of Chicago Press.

Cavaillé, C. (2014). Regulating free-riding: How differences in moral reasoning shape support for redistributive social policies. Paper presented at the Annual Meeting of the American Political Science Association, August 2014.

Cavaillé, C. (2015). Deservingness, self-interest and the welfare state: Why some care more about deservingness than others and why it matters. IAST Working Paper.

Cunningham, M. (2007). Influences of women's employment on the gendered division of household labour over the life course - evidence from a 31-year panel study. Journal of Family Issues, 28(3), 422-444.

Erosa, A., Fuster, L., \& Restuccia, D. (2010). A general equilibrium analysis of parental leave policies. Review of Economic Dynamics, 13(4), 742-758.

Esping-Andersen, G. (1990). The three worlds of welfare capitalism. Princeton, N.J.: Princeton University Press.

Estévez-Abe, M. (2005). Gender bias in skills and social policies: The varieties of capitalism perspective on sex segregation. Social Politics, 12(2), 180-215.

Estévez-Abe, M. (2006). Gendering the varieties of capitalism - a study of occupational segregation by sex in advanced industrial societies. World Politics, 59(1), 142-175.

Estévez-Abe, M., Iversen, T., \& Soskice, D. (2001). Social protection and formation of skills: A reinterpretation of the welfare state. In P. A. Hall \& D. Soskice (Eds.), Varieties of capitalism: The institutional foundations of comparative advantage. Oxford, U.K.: Oxford University Press.

Ferragina, E., Seeleib-Kaiser, M., \& Tomlinson, M. (2012). Welfare regime theory: A house of cards? Unemployment protection and family policy at the turn of the 21st century. Working paper, Oxford Institute of Social Policy.

Fleckenstein, T., Saunders, A. M., \& Seeleib-Kaiser, M. (2011). The dual transformation of social protection and human capital: Comparing Britain and Germany. Comparative Political Studies, 44(12), 1622-1650.

Gingrich, J. R. (2014). Visibility, Values, and Voters: The Informational Role of the Welfare State. The Journal of Politics, 76(2), 565-580.

Gingrich, J. R., \& Ansell, B. W. (2012). Preferences in context: Micro preferences, macro contexts, and the demand for social policy. Comparative Political Studies, 45, 1624-1654.

Goldin, C. (2006). The quiet revolution that transformed women's employment, education, and family. American Economic Review, 96(2), 1-21.

Goldin, C., \& Katz, L. F. (2011). The career cost of family. NBER Working Paper.

Hall, P. A., \& Soskice, D. (2001). Varieties of capitalism: The institutional foundations of comparative advantage. Oxford, U.K.: Oxford University Press.

Hanmer, M. J., \& Ozan Kalkan, K. (2012). Behind the Curve: Clarifying the Best Approach to Calculating Predicted Probabilities and Marginal Effects from Limited Dependent Variable Models. American Journal of Political Science, 57(1), 263-277. 
Häusermann, S. (2006). Different paths of family policy modernization in continental welfare states. Paper prepared for the annual conference of the Swiss Political Science Association, Balsthal, November 2-3, 2006.

Häusermann, S., \& Schwander, H. (2012). Varieties of dualization? Labour market segmentation and insider-outsider divides across regimes. In P. Emmenegger, S. Häusermann, B. Palier, \& M. Seeleib-Kaiser (Eds.), The age of dualization: The changing face of inequality in deindustrializing societies (pp. 27-51). Oxford, U.K.; New York, N.Y.: Oxford University Press.

Hinnfors, J. (1999). Stability through change: The pervasiveness of political ideas. Journal of Public Policy, 19(3), 293-312.

Hochschild, A. R., \& Machung, A. (1989). The second shift: Working parents and the revolution at home. New York, N.Y.: Viking.

Huber, E., \& Stephens, J. D. D. (2000). Partisan governance, women's employment, and the social democratic service state. American Sociological Review, 65(3), 323-342.

Huber, E., \& Stephens, J. D. D. (2001). Development and crisis of the welfare state: Parties and policies in global markets. Chicago, Ill.: The University of Chicago Press.

Idema, T., \& Rueda, D. (2011). Redistribution preferences and life-cycle income. Working paper, University of Oxford.

Inglehart, R., \& Norris, P. (2000). The developmental theory of the gender gap: Women's and men's voting behavior in global perspective. International Political Science Review, 21(4), 441-463.

Inglehart, R., \& Norris, P. (2003). Rising tide: Gender equality and cultural change around the world. Cambridge, U.K.,; New York, N.Y.: Cambridge University Press.

Iversen, T. (2005). Capitalism, democracy, and welfare. Cambridge, U.K.,; New York, N.Y.: Cambridge University Press.

Iversen, T., \& Cusack, T. (2000). The causes of welfare state expansion: Deindustrialization or globalization? World Politics, 52(3), 313-349.

Iversen, T., \& Rosenbluth, F. (2006). The political economy of gender: Explaining cross-national variation in the gender division of labour and the gender voting gap. American Journal of Political Science, 50(1), 1-19.

Iversen, T., \& Rosenbluth, F. (2010). Women, work, and politics: The political economy of gender inequality. New Haven, Conn.: Yale University Press.

Iversen, T., \& Soskice, D. (2015). Democratic Limits to redistribution: Inclusionary versus Exclusionary Coalitions in the Knowledge Economy. World Politics, 67(02), 185-225.

Jensen, C. (2011). The forgotten half: Analysing the politics of welfare services. International Journal of Social Welfare, 20(4), 404-412.

King, E. M., \& Mason, A. D. (2001). Engendering development through gender equality in rights, resources, and voice. Washington: World Bank; Oxford University Press.

Konrad, A. M., \& Cannings, K. (1997). The effects of gender role congruence and statistical discrimination on managerial advancement. Human Relations, 50(10), 1305-1328.

Leira, A. (2002). Working parents and the welfare state: Family change and policy reform in Scandinavia. Cambridge, U.K.: Cambridge University Press.

Lundberg, S. (2008). Gender and household decision-making. In F. Bettio \& A. Verashchagina (Eds.), Frontiers in the economics of gender (pp. 116-134). London, U.K.,; New York, N.Y.: Routledge.

Lundberg, S., \& Pollak, R. A. (2008). Family decision-making. In S. N. Durlauf \& L. Blume (Eds.), The new Palgrave dictionary of economics (2nd ed.). Basingstoke Hampshire: Palgrave Macmillan.

Mahon, R. (2002). Gender and welfare state restructuring: Through the lens of child care. In S. Michel \& R. Mahon (Eds.), Child care policy at the crossroads: Gender and welfare state restructuring (pp. 1-27). New York, N.Y.: Routledge.

Meltzer, A. H., \& Richard, S. F. (1981). A rational theory of the size of government. Journal of Political Economy, 89(5), 914-927. 
Michel, S., \& Mahon, R. (2002). Child care policy at the crossroads: Gender and welfare state restructuring. New York, N.Y.: Routledge.

Morel, N., Palier, B., \& Palme, J. (2012). Towards a social investment welfare state?: Ideas, policies and challenges. Bristol, U.K.: The Policy Press.

Morgan, K. J. (2006). Working mothers and the welfare state: Religion and the politics of work-family policies in Western Europe and the United States. Stanford: Stanford University Press.

Morgan, K. J. (2012). Promoting social investment through work-family policies: Which nations do it and why? In N. Morel, B. Palier, \& J. Palme (Eds.), Towards a social investment welfare state?: Ideas, policies and challenges. Bristol, U.K.: The Policy Press.

Morgan, K. J. (2013). Path shifting of the welfare state: Electoral competition and the expansion of work-family policies in Western Europe. World Politics, 65(01), 73-115.

Moss, P. (2012). International review of leave policies and related research 2012. Vienna: International Network on Leave Policies and Research, Austrian Institute for Family Studies, University of Vienna.

Munasinghe, L., Reif, T., \& Henriques, A. (2008). Gender gap in wage returns to job tenure and experience. Labour Economics, 15(6), 1296-1316.

OECD. (2012a). OECD family database: PF2.2 - use of childbirth-related leave by mothers and fathers. Paris, France: OECD; OECD.

OECD. (2012b). Social Expenditure: Aggregated data. OECD Social Expenditure Statistics. Paris, France: Paris: OECD; OECD.

Pfau-Effinger, B. (1998). Gender cultures and the gender arrangement - a theoretical framework for cross-national gender research. Innovation: The European Journal of Social Science Research, 11(2), 147-166.

Pfau-Effinger, B. (2004). Development of culture, welfare states and women's employment in Europe. Aldershot: Ashgate.

Pierson, P. (1996). The new politics of the welfare state. World Politics, 48(2), $143-\&$.

Pierson, P. (2000). Three worlds of welfare state research. Comparative Political Studies, 33(6-7), 791-821.

Piketty, T. (2013). Le capital au xxie siècle. Paris, France: Seuil.

Rasmussen, A. W. (2010). Increasing the length of parents' birth-related leave: The effect on children's long-term educational outcomes. Labour Economics, 17(1), 91-100.

Rehm, P. (2011). Social policy by popular demand. World Politics, 63(2), 271-299.

Ross, M. L. (2008). Oil, islam, and women. American Political Science Review, 102(1), 107-123.

Rueda, D. (2007). Social democracy inside out: Partisanship and labour market policy in industrialized democracies. Oxford, U.K.: Oxford University Press.

Rønsen, M., \& Sundström, M. (1996). Maternal employment in Scandinavia: A comparison of the after-birth employment activity of Norwegian and Swedish women. Journal of Population Economics, 9(3), 267-285.

Solt, F. (2009). Standardizing the World Income Inequality Database*. Social Science Quarterly, 90(2), 231-242.

Thelen, K. (2004). How institutions evolve: The political economy of skills in germany, britain, the united states, and japan. Cambridge, U.K.; New York, N.Y.: Cambridge University Press.

Thevenon, O., \& Solaz, A. (2013). Labour market effects of parental leave policies in OECD countries. OECD Social, Employment and Migration Working Papers, no. 141.

World Bank. (2012). World development indicators. World Bank, Washington, DC.

Xu, Z. (2007). A survey on intra-household models and evidence. MPRA Working Paper No. 3763, University of Munich. 


\section{Appendix}

Table A-1. Summary statistics for the independent variables

\begin{tabular}{|c|c|c|c|c|c|c|c|c|c|c|}
\hline & \multicolumn{5}{|c|}{1994 survey } & \multicolumn{5}{|c|}{2002 survey } \\
\hline & Mean & SD & Min & Max & Obs. & Mean & SD & Min & Max & Obs. \\
\hline Female & 0.53 & 0.50 & 0 & 1 & 22121 & 0.53 & 0.50 & 0 & 1 & 25616 \\
\hline Higher education & 0.12 & 0.32 & 0 & 1 & 19509 & 0.16 & 0.37 & 0 & 1 & 25652 \\
\hline \multicolumn{11}{|l|}{ Employment status } \\
\hline Stay-at-home & 0.14 & 0.34 & 0 & 1 & 21883 & 0.10 & 0.31 & 0 & 1 & 25228 \\
\hline \multicolumn{2}{|c|}{ Full-time employment 0.47} & 0.50 & 0 & 1 & 21883 & 0.46 & 0.50 & 0 & 1 & 25228 \\
\hline \multicolumn{2}{|c|}{ Part-time employment0.07 } & 0.26 & 0 & 1 & 21883 & 0.10 & 0.30 & 0 & 1 & 25228 \\
\hline Unemployed & 0.05 & 0.22 & 0 & 1 & 21883 & 0.04 & 0.19 & 0 & 1 & 25228 \\
\hline Student/apprentice & 0.07 & 0.25 & 0 & 1 & 21883 & 0.06 & 0.23 & 0 & 1 & 25228 \\
\hline Retired & 0.15 & 0.36 & 0 & 1 & 21883 & 0.19 & 0.39 & 0 & 1 & 25228 \\
\hline Other & 0.05 & 0.21 & 0 & 1 & 21883 & 0.04 & 0.21 & 0 & 1 & 25228 \\
\hline \multicolumn{11}{|l|}{ Spouse's empl. status } \\
\hline Stay-at-home & 0.07 & 0.26 & 0 & 1 & 21373 & 0.07 & 0.26 & 0 & 1 & 24978 \\
\hline \multicolumn{2}{|c|}{ Full-time employment 0.04} & 0.20 & 0 & 1 & 21373 & 0.06 & 0.24 & 0 & 1 & 24978 \\
\hline \multicolumn{2}{|c|}{ Part-time employment0.29 } & 0.45 & 0 & 1 & 21373 & 0.34 & 0.47 & 0 & 1 & 24978 \\
\hline Unemployed & 0.02 & 0.13 & 0 & 1 & 21373 & 0.01 & 0.12 & 0 & 1 & 24978 \\
\hline Student/apprentice & 0.01 & 0.08 & 0 & 1 & 21373 & 0.01 & 0.10 & 0 & 1 & 24978 \\
\hline Retired & 0.08 & 0.27 & 0 & 1 & 21373 & 0.12 & 0.32 & 0 & 1 & 24978 \\
\hline Other & 0.02 & 0.15 & 0 & 1 & 21373 & 0.02 & 0.15 & 0 & 1 & 24978 \\
\hline Do not have a spouse & 0.47 & 0.50 & 0 & 1 & 21373 & 0.36 & 0.48 & 0 & 1 & 24978 \\
\hline \multicolumn{11}{|l|}{ Income tertile } \\
\hline Lower & 0.35 & 0.48 & 0 & 1 & 15399 & 0.35 & 0.48 & 0 & 1 & 20202 \\
\hline Middle income & 0.33 & 0.47 & 0 & 1 & 15399 & 0.34 & 0.47 & 0 & 1 & 20202 \\
\hline Upper & 0.32 & 0.47 & 0 & 1 & 15399 & 0.32 & 0.46 & 0 & 1 & 20202 \\
\hline Cohort & 1949.35 & 16.93 & 1896 & 1979 & 21993 & 1955.67 & 17.22 & 1906 & 1987 & 25551 \\
\hline Dependents & 1.35 & 1.36 & 0 & 5 & 17341 & 1.00 & 1.22 & 0 & 5 & 25137 \\
\hline Church attendance & 1.53 & 1.79 & 0 & 5 & 21731 & 1.64 & 1.72 & 0 & 5 & 25005 \\
\hline
\end{tabular}


Table A-2. OLS regression results from a set of linear probability models

\begin{tabular}{|c|c|c|c|c|c|c|c|c|}
\hline & \multicolumn{4}{|c|}{ Day care } & \multicolumn{4}{|c|}{ Paid leave } \\
\hline & (1) & (2) & (3) & (4) & (5) & (6) & (7) & (8) \\
\hline Female & $\begin{array}{l}0.04^{\text {***}} \\
(0.01)\end{array}$ & $\begin{array}{l}0.09^{*} \\
(0.05)\end{array}$ & $\begin{array}{l}-0.07^{\star *} \\
(0.03)\end{array}$ & $\begin{array}{l}-0.02 \\
(0.08)\end{array}$ & $\begin{array}{l}0.04^{\text {***}} \\
(0.01)\end{array}$ & $\begin{array}{l}0.03 \\
(0.04)\end{array}$ & $\begin{array}{l}-0.02 \\
(0.03)\end{array}$ & $\begin{array}{l}-0.03 \\
(0.06)\end{array}$ \\
\hline University & $\begin{array}{l}0.04^{* * \star} \\
(0.01)\end{array}$ & $\begin{array}{l}0.04^{* * *} \\
(0.01)\end{array}$ & $\begin{array}{l}0.01 \\
(0.01)\end{array}$ & $\begin{array}{l}0.01 \\
(0.02)\end{array}$ & $\begin{array}{l}0.04^{\star * \star} \\
(0.01)\end{array}$ & $\begin{array}{l}0.04^{* * \star} \\
(0.01)\end{array}$ & $\begin{array}{l}0.02^{*} \\
(0.01)\end{array}$ & $\begin{array}{l}0.01 \\
(0.01)\end{array}$ \\
\hline Female $\mathrm{x}$ university & & & $\begin{array}{l}0.07^{\star * *} \\
(0.01)\end{array}$ & $\begin{array}{l}0.07^{\star * *} \\
(0.02)\end{array}$ & & & $\begin{array}{l}0.05^{* * *} \\
(0.02)\end{array}$ & $\begin{array}{l}0.05^{* * *} \\
(0.02)\end{array}$ \\
\hline \multicolumn{9}{|c|}{ Employment (ref.: stay-at-home) } \\
\hline Full-time & $\begin{array}{l}0.10^{\star \star \star} \\
(0.01)\end{array}$ & $\begin{array}{l}0.09^{\star * \star} \\
(0.02)\end{array}$ & $\begin{array}{l}-0.01 \\
(0.04)\end{array}$ & $\begin{array}{l}-0.01 \\
(0.05)\end{array}$ & $\begin{array}{l}0.03^{\star \star \star} \\
(0.01)\end{array}$ & $\begin{array}{l}0.01 \\
(0.01)\end{array}$ & $\begin{array}{l}-0.02 \\
(0.03)\end{array}$ & $\begin{array}{l}-0.04 \\
(0.04)\end{array}$ \\
\hline Part-time & $\begin{array}{l}0.08^{\star \star *} \\
(0.02)\end{array}$ & $\begin{array}{l}0.06^{* * *} \\
(0.02)\end{array}$ & $\begin{array}{l}-0.04 \\
(0.04)\end{array}$ & $\begin{array}{l}0.00 \\
(0.06)\end{array}$ & $\begin{array}{l}0.04^{* * *} \\
(0.01)\end{array}$ & $\begin{array}{l}0.03^{* *} \\
(0.01)\end{array}$ & $\begin{array}{l}-0.02 \\
(0.03)\end{array}$ & $\begin{array}{l}-0.01 \\
(0.04)\end{array}$ \\
\hline Unemployed & $\begin{array}{l}0.11^{\star \star \star} \\
(0.02)\end{array}$ & $\begin{array}{l}0.09^{\star \star \star} \\
(0.02)\end{array}$ & $\begin{array}{l}0.00 \\
(0.04)\end{array}$ & $\begin{array}{l}-0.00 \\
(0.06)\end{array}$ & $\begin{array}{l}0.06^{\star \star \star} \\
(0.01)\end{array}$ & $\begin{array}{l}0.05^{\star \star \star} \\
(0.02)\end{array}$ & $\begin{array}{l}-0.00 \\
(0.03)\end{array}$ & $\begin{array}{l}-0.01 \\
(0.05)\end{array}$ \\
\hline Student/apprentice & $\begin{array}{l}0.10^{\star \star \star} \\
(0.02)\end{array}$ & $\begin{array}{l}0.05^{\star *} \\
(0.02)\end{array}$ & $\begin{array}{l}-0.02 \\
(0.04)\end{array}$ & $\begin{array}{l}-0.04 \\
(0.06)\end{array}$ & $\begin{array}{l}0.05^{\star \star *} \\
(0.01)\end{array}$ & $\begin{array}{l}0.02 \\
(0.02)\end{array}$ & $\begin{array}{l}-0.02 \\
(0.04)\end{array}$ & $\begin{array}{l}-0.03 \\
(0.05)\end{array}$ \\
\hline Retired & $\begin{array}{l}-0.04^{\star \star} \\
(0.02)\end{array}$ & $\begin{array}{l}0.08^{* * *} \\
(0.02)\end{array}$ & $\begin{array}{l}-0.12^{* * *} \\
(0.04)\end{array}$ & $\begin{array}{l}0.01 \\
(0.05)\end{array}$ & $\begin{array}{l}-0.04^{* * *} \\
(0.01)\end{array}$ & $\begin{array}{l}0.04^{\star *} \\
(0.02)\end{array}$ & $\begin{array}{l}-0.07^{*} \\
(0.04)\end{array}$ & $\begin{array}{l}0.00 \\
(0.04)\end{array}$ \\
\hline Other & $\begin{array}{l}0.05^{\star \star} \\
(0.02)\end{array}$ & $\begin{array}{l}0.08^{* * *} \\
(0.02)\end{array}$ & $\begin{array}{l}-0.01 \\
(0.05)\end{array}$ & $\begin{array}{l}0.02 \\
(0.07)\end{array}$ & $\begin{array}{l}-0.00 \\
(0.01)\end{array}$ & $\begin{array}{l}0.01 \\
(0.01)\end{array}$ & $\begin{array}{l}-0.04 \\
(0.04)\end{array}$ & $\begin{array}{l}-0.03 \\
(0.05)\end{array}$ \\
\hline \multicolumn{9}{|l|}{ Female $\mathrm{x}$} \\
\hline Full-time & & & $\begin{array}{l}0.13^{\star \star \star} \\
(0.04)\end{array}$ & $\begin{array}{l}0.13^{* *} \\
(0.05)\end{array}$ & & & $\begin{array}{l}0.06^{*} \\
(0.03)\end{array}$ & $\begin{array}{l}0.07 \\
(0.04)\end{array}$ \\
\hline Part-time & & & $\begin{array}{l}0.13^{* * *} \\
(0.04)\end{array}$ & $\begin{array}{l}0.06 \\
(0.06)\end{array}$ & & & $\begin{array}{l}0.07^{\star \star} \\
(0.03)\end{array}$ & $\begin{array}{l}0.05 \\
(0.03)\end{array}$ \\
\hline Unemployed & & & $\begin{array}{l}0.12^{\star * *} \\
(0.04)\end{array}$ & $\begin{array}{l}0.09 \\
(0.06)\end{array}$ & & & $\begin{array}{l}0.07 \\
(0.04)\end{array}$ & $\begin{array}{l}0.06 \\
(0.05)\end{array}$ \\
\hline Student/apprentice & & & $\begin{array}{l}0.13^{* * *} \\
(0.05)\end{array}$ & $\begin{array}{l}0.10 \\
(0.07)\end{array}$ & & & $\begin{array}{l}0.09^{\star \star} \\
(0.04)\end{array}$ & $\begin{array}{l}0.07 \\
(0.05)\end{array}$ \\
\hline Retired & & & $\begin{array}{l}0.07 \\
(0.04)\end{array}$ & $\begin{array}{l}0.05 \\
(0.05)\end{array}$ & & & $\begin{array}{l}-0.00 \\
(0.04)\end{array}$ & $\begin{array}{l}0.02 \\
(0.05)\end{array}$ \\
\hline Other & & & $\begin{array}{l}0.05 \\
(0.05)\end{array}$ & $\begin{array}{l}0.05 \\
(0.06)\end{array}$ & & & $\begin{array}{l}0.04 \\
(0.04)\end{array}$ & $\begin{array}{l}0.04 \\
(0.05)\end{array}$ \\
\hline \multicolumn{9}{|c|}{ Income (ref.: lower tertile) } \\
\hline Medium & & $\begin{array}{l}-0.02^{\star * \star} \\
(0.01)\end{array}$ & & $\begin{array}{l}-0.02^{\star * *} \\
(0.01)\end{array}$ & & $\begin{array}{l}0.00 \\
(0.01)\end{array}$ & & $\begin{array}{l}0.00 \\
(0.01)\end{array}$ \\
\hline Upper & & $\begin{array}{l}-0.04^{\star * *} \\
(0.01)\end{array}$ & & $\begin{array}{l}-0.04^{* \star *} \\
(0.01)\end{array}$ & & $\begin{array}{l}-0.00 \\
(0.01)\end{array}$ & & $\begin{array}{l}-0.00 \\
(0.01)\end{array}$ \\
\hline Country fixed effects & Yes & Yes & Yes & Yes & Yes & Yes & Yes & Yes \\
\hline Year fixed effects & Yes & Yes & Yes & Yes & Yes & Yes & Yes & Yes \\
\hline Covariates & & Yes & & Yes & & Yes & & Yes \\
\hline $\mathrm{N}$ & 44,468 & 33,111 & 44,468 & 33,111 & 44,468 & 33,111 & 44,468 & 33,111 \\
\hline
\end{tabular}

